\title{
Macular pigment deposits in rhegmatogenous retinal detachment
}

\author{
G. P. THEODOSSIADIS AND S. N. KOKOLAKIS \\ From the Retinal Department of Athens University Eye Clinic, Athens, Greece
}

SUMMARY This is a study of 20 cases of macular pigment migration after operation for retinal detachment. The frequency of pigment deposits on the macula among the total number of operated detachments was $6.4 \%$. The evolution of pigment migration depended on the form and type of the deposits. In some cases the pigment diminished or disappeared. In 6 of the 20 eyes with pigment migration puckering of the macula occurred 4 months or more after surgery. The improvement in visual acuity 6 months and more after operation was relatively less in the group with pigment deposits than in the group without pigment. In the former group static perimetry showed defects corresponding to the pigment migration.

Pigment migration or dispersal or fallout maybe a complication of rhegmatogenous retinal detachment or of retinal detachment surgery with cryoapplication. First described by Bietti (1934a, b), it is attributed to the release of pigment from the pigment epithelium in an area previously subjected to freezing. The pigment thus released is conveyed by the ocular fluids and deposited in various parts of the eye fundus. The pigment travels either transvitreally or by way of the subretinal fluid (Sudarsky and Yannuzzi, 1970; Hamilton and Taylor, 1972).

Various authors, such as Lincoff (1967), Abraham and Shea (1969), Sudarsky and Yannuzzi (1970), Chignell et al. (1973), Hilton (1974), and Theodossiadis et al. (1975b), have previously discussed the general aspects of pigment dispersal and with its causes, without, however, confining themselves exclusively to the migration of pigment to the macula and its consequences. The present study therefore aims at describing the incidence of pigment fallout in the macula, its evolution, and the effects of pigment deposits on the function of the macula.

\section{Material and methods}

Our investigation is based on 326 cases of rhegmatogenous retinal detachment operated on between January 1974 and January 1976. During this period a total of 402 rhegmatogenous retinal detachments were surgically treated. Anatomical restoration was

Address for reprints: Dr G. P. Theodossiadis, 54 Omirou Street, Athens (135), Greece achieved in 357 of these cases after one or more surgical operations. Of these 357 cases our investigation takes into account 326 , the remaining 31 cases having been excluded as they could not be adequately studied.

The operation in all cases was in accordance with the Custodis-Lincoff procedure, which entails the placing of an episcleral Silastic sponge in conjunction with cryopexy. Drainage was employed in 152 of these 326 cases. In all instances the cryoprobe was applied under ophthalmoscopic control.

Of the total number of 326 cases 72 presented pigment migration into one or more retinal areas; 21 out of the 72 cases showed pigment deposits at least in the central part of the retina, that is, in the macula or the fovea or the foveola. It should be stressed that the group of patients with pigment migration in the macula includes only eyes with manifest pigment deposits. Cases with sparse pigment spots were not taken into consideration.

Of the 21 cases showing pigment deposits in the macula only 20 (group $A$ ) were followed up and examined, 1 case being eliminated because of macular puckering prior to the operation for retinal detachment. None of the 20 patients with macular pigment migration had been given a saline or air injection into the vitreous cavity during surgery. Of the 20 cases 2 showed pigment deposits confined solely to the fovea and foveola, whereas in the remaining 18 cases the deposits involved in addition to the fovea and foveola one or more retinal areas.

Depending on its form, pigment migration was classified into the spotty, patchy, striated, and mixed types. The spotty type included pigment accumula- 
Table 1 Comparison of groups A and B regarding sex, aphakia, location of tears, number of cryoapplications, manner of Silastic sponge fixation, release or nonrelease of subretinal fluid, and postoperative uveitis

\begin{tabular}{|c|c|c|c|c|c|c|c|}
\hline \multirow{2}{*}{$\begin{array}{l}\text { Case } \\
\text { no. }\end{array}$} & \multicolumn{7}{|c|}{ Group A (with macular pigment migration) } \\
\hline & Sex & Aphakia & $\begin{array}{l}\text { Location } \\
\text { of tears }\end{array}$ & $\begin{array}{l}\text { No. of } \\
\text { cryoapplication }\end{array}$ & $\begin{array}{l}\text { Fixation of } \\
\text { Silastic sponge }\end{array}$ & $\begin{array}{l}\text { Release of } \\
\text { subretinal fluid }\end{array}$ & $\begin{array}{l}\text { Postoperative } \\
\text { uveitis }\end{array}$ \\
\hline 1 & $\mathbf{M}^{*}$ & + & $\mathrm{SN} \dagger$ & 21 & $\mathrm{E}-\mathrm{R} \ddagger$ & + & - \\
\hline 2 & $\mathrm{~F}$ & + & SN-IN & 27 & $\mathrm{E}$ & - & - \\
\hline 3 & $\mathbf{M}$ & + & ST & 14 & $\mathrm{E}$ & + & + \\
\hline 4 & $\mathrm{~F}$ & - & ST & 7 & $P$ & + & + \\
\hline 5 & M & - & ST & 5 & $\mathrm{E}$ & + & $\div$ \\
\hline 6 & $\mathbf{F}$ & $\cdots$ & ST-IN & 10 & $E$ & + & - \\
\hline 7 & M & - & ST-SN & 7 & $\mathrm{P}-\mathrm{R}$ & + & - \\
\hline 8 & $M$ & & ST-IN & 7 & $\mathrm{E}$ & - & - \\
\hline 9 & $\mathbf{M}$ & - & ST-IT & 25 & $\mathrm{P}$ & $!$ & + \\
\hline 10 & $\mathbf{M}$ & - & $\mathrm{SN}-\mathrm{IT}$ & 17 & $\mathbf{P}$ & - & + \\
\hline 11 & $\mathrm{~F}$ & - & $\mathrm{ST}$ & 22 & $\mathbf{P}$ & - & - \\
\hline 12 & $\mathbf{M}$ & - & $\mathrm{ST}$ & 8 & $\mathbf{R}$ & - & + \\
\hline 13 & $F$ & - & ST & 12 & $\mathbf{P}$ & - & + \\
\hline 14 & $\mathbf{M}$ & + & ST & 9 & $E$ & + & + \\
\hline 15 & $\mathbf{M}$ & - & ST & 11 & $\mathbf{P}$ & + & + \\
\hline 16 & $\mathbf{M}$ & & SN-IT & 6 & $\mathrm{E}$ & - & + \\
\hline 17 & $F$ & - & $\mathrm{ST}$ & 5 & $\mathbf{P}$ & - & + \\
\hline 18 & $\mathbf{M}$ & - & ST-IT & 21 & $\mathbf{P}$ & - & + \\
\hline 19 & $\mathbf{M}$ & $\div$ & SN & 13 & $\mathrm{E}$ & + & - \\
\hline 20 & $\mathrm{~F}$ & - & ST & 15 & $\mathbf{P}-\mathbf{R}$ & - & + \\
\hline \multirow{2}{*}{$\begin{array}{l}\text { Case } \\
\text { no. }\end{array}$} & \multicolumn{7}{|c|}{ Group B (without pigment migration) } \\
\hline & Sex & Aphakia & $\begin{array}{l}\text { Location } \\
\text { of tears }\end{array}$ & $\begin{array}{l}\text { No. of } \\
\text { cryoapplications }\end{array}$ & $\begin{array}{l}\text { Fixation of } \\
\text { Silastic sponge }\end{array}$ & $\begin{array}{l}\text { Release of } \\
\text { subretinal fluid }\end{array}$ & $\begin{array}{l}\text { Postoperative } \\
\text { uveitis }\end{array}$ \\
\hline 1 & $\mathrm{~F}$ & - & IN & 5 & $\mathbf{P}$ & + & - \\
\hline 2 & $\mathbf{M}$ & - & IT & 8 & $\mathrm{E}$ & - & - \\
\hline 3 & $\mathrm{~F}$ & + & ST-SN & 11 & $\mathrm{E}$ & + & - \\
\hline 4 & $\mathbf{M}$ & - & ST & 15 & $\mathbf{P}$ & - & - \\
\hline 5 & $\mathbf{M}$ & + & SN-IT & 16 & $\mathrm{E}$ & - & + \\
\hline 6 & $\mathbf{M}$ & + & ST & 10 & $\mathrm{E}$ & $\dot{+}$ & - \\
\hline 7 & $\mathrm{~F}$ & - & ST & 10 & $\mathbf{R}-\mathbf{P}$ & + & - \\
\hline 8 & $\mathbf{M}$ & - & IT & 6 & $\mathrm{E}$ & + & - \\
\hline 9 & $F$ & - & IT-IN & 22 & $\mathbf{P}$ & + & - \\
\hline 10 & $\mathbf{M}$ & + & SN & 7 & $\mathrm{E}$ & + & - \\
\hline 11 & $\mathrm{~F}$ & - & IT & 20 & $\mathbf{P}$ & - & - \\
\hline 12 & $\mathbf{M}$ & - & ST & 6 & $\mathbf{P}$ & - & - \\
\hline 13 & $F$ & - & SN & 21 & $\mathbf{P}$ & + & - \\
\hline 14 & $\mathrm{~F}$ & - & ST & 12 & $E$ & $\div$ & - \\
\hline 15 & $\mathbf{M}$ & - & ST & 14 & $\mathbf{P}$ & - & - \\
\hline 16 & $\mathbf{M}$ & - & SN-IN & 14 & E-R & $\therefore$ & - \\
\hline 17 & $\mathbf{M}$ & - & SN & 10 & $\mathbf{P}-\mathbf{R}$ & - & - \\
\hline 18 & $\mathbf{M}$ & - & $\mathrm{ST}$ & 15 & $\mathbf{P}$ & $\div$ & - \\
\hline 19 & $\mathbf{F}$ & - & SN & 11 & $\mathbf{P}$ & + & - \\
\hline 20 & $\mathbf{M}$ & + & ST & 13 & $\mathbf{P}$ & - & - \\
\hline
\end{tabular}

* $\mathbf{M}=$ male, $\mathbf{F}=$ female. $\quad+\mathrm{ST}=$ superior temporal, $\mathrm{SN}=$ superior nasal, $\mathbf{I T}=$ inferior temporal, $\mathbf{I N}=$ inferior nasal. $\ddagger \mathbf{E}=$ encircling, $\mathbf{R}=$ radial, $\mathbf{P}=$ parallel to the limbus 
tions in the fovea and foveola. Each accumulation comprised at least five or more spots of pinhead size. In accordance with the location of the pigment deposits these were divided into epiretinal and subretinal types.

To study the effects of the pigment deposits on the function of the macula we also examined an equal number of cases operated on for rhegmatogenous retinal detachment in accordance with the same method and by the same surgeons but lacking pigment deposits. The patients selected (group $B$ ) corresponded approximately to those with pigment migration in the macula (group $A$ ) in respect of age, refraction, extent of the detachment, macular involvement, and preoperative visual acuity. The cases in the control group, like those of group $A$, showed no preoperative degeneration or other alterations of the macula.

Table 1 sets out the sex, the presence or absence of aphakia, the location of the tears, the number of cryoapplications, the manner of placement of the Silastic sponge, the release or nonrelease of subretinal fluid, and postoperative uveitis in the patients of both groups. Temperature and duration of the cryoapplication were about the same in both groups. The temperature ranged from -45 to $-60^{\circ} \mathrm{C}$ and the duration of the cryoapplication from 3 to 8 seconds, the average being 6.5 seconds.

During the follow-up of the cases of both groups at regular intervals visual acuity was examined, colour perception ascertained by means of the 100 hue test, photographs were taken and fluorescein angiography was carried out. Moreover, the patients were subjected to an examination with direct and indirect ophthalmoscopy, the Goldmann threecontact-lens, as well as to ERG and both kinetic and static perimetry. The duration of the follow-up period amounted to at least 24 months.

\section{Results}

FREQUENCY OF MACULAR PIGMENT DEPOSITS The relative frequency of pigment migration and deposits in the macula amounted to $6.4 \%$ of the total number of retinal detachments. More specifically, of the 20 cases 8 concerned the foveola and 10 the fovea, while the remaining 2 cases were of the mixed type.

Analysis of the factors listed in Table 1 showed that some of them influenced pigment migration, while others were entirely irrelevant. Among the factors which exerted no influence on pigment migration were sex, aphakia, the manner of Silastic sponge fixation, and the release or nonrelease of the subretinal fluid. Among the factors that certainly operated should be reckoned postoperative uveitis
Table 2 Type and location of pigment deposits in relation to macular elevation and puckering

\begin{tabular}{rllll}
\hline $\begin{array}{l}\text { Case } \\
\text { no. }\end{array}$ & $\begin{array}{l}\text { Pigment } \\
\text { type }\end{array}$ & $\begin{array}{l}\text { Location } \\
\text { of deposits }\end{array}$ & $\begin{array}{l}\text { Macular } \\
\text { detachment }\end{array}$ & $\begin{array}{l}\text { Macular } \\
\text { puckering }\end{array}$ \\
\hline 1 & Sp.* & Epir. & - & $+4 \mathrm{~m} \dagger$ \\
2 & Sp. & Epir. & + & $+5 \mathrm{~m}$ \\
3 & Sp. & Subr. & + & - \\
4 & Sp.-pat. & Subr. & + & $+6 \mathrm{~m}$ \\
5 & Pat. & Subr. & + & - \\
6 & Pat. & Subr. & + & - \\
7 & Sp. & Subr. & + & - \\
8 & Sp. & Subr. & + & - \\
9 & Pat. & Subr. & + & - \\
10 & Pat. & Subr. & + & - \\
11 & Sp.-pat. & Epir.-subr. & + & - \\
12 & Sp.-str. & Epir. & - & $+5 \mathrm{~m}$ \\
13 & Sp.-str. & Epir. & - & - \\
14 & Pat. & Subr. & + & - \\
15 & Sp. & Epir. & + & - \\
16 & Sp.-pat. & Subr. & + & - \\
17 & Sp. & Epir. & - & - \\
18 & Sp. & Epir. & - & - \\
19 & Sp. & Epir. & - & $+4 \mathrm{~m}$ \\
20 & Sp.-pat. & Epir. & + & $+4 \mathrm{~m}$ \\
\hline
\end{tabular}

* Sp. = spotty, pat. = patchy, str. = striated, epir. = epiretinal subr. $=$ subretinal. $+\mathrm{m}=$ months after retinal detachment surgery

Table 3 Time of onset of pigment migration in relation to the time of operation

\begin{tabular}{llll}
\hline Time & Preoperatively & $\begin{array}{l}\text { During or immediately } \\
\text { after operation }\end{array}$ & $\begin{array}{l}\text { Postoperatively } \\
\text { (up to 10 days) }\end{array}$ \\
\hline Cases & 4 & 13 & 3 \\
\hline
\end{tabular}

and retinal tears located at the upper temporal quadrant and especially at the superior quadrants $(\mathrm{P}<0.025)$, while the number of cryoapplications should be taken into account in relation to the degree of temperature, the duration of each application and the degree of pressure exerted with the probe on the eyeball (Brihaye and Oosterhuis, 1972).

Details as to the form of pigment deposits, the elevation or absence of elevation of the macula, and the presence of macular puckering in conjunction with the time of its development after surgery for detachment are summarised in Table 2. Finally, Table 3 sets out the time of onset of pigment migration in relation to the time of surgery for the retinal detachment.

The analysis shows that preoperative pigment migration was observed mainly in aphakic eyes, in which the detachment appeared as long as $\mathbf{4}$ months after the operation for cataract, as well as in cases with highly elevated retina, the eyes of which were patched for 24 to 48 hours prior to the surgical 


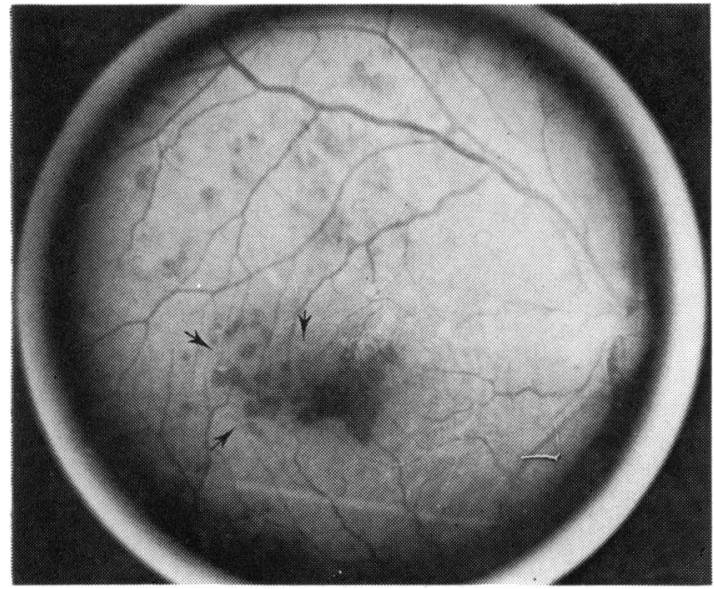

Fig. 1 Subretinal pigment deposits in the central area 4 months after successful retinal detachment operation. Visual acuity $0 \cdot 4$

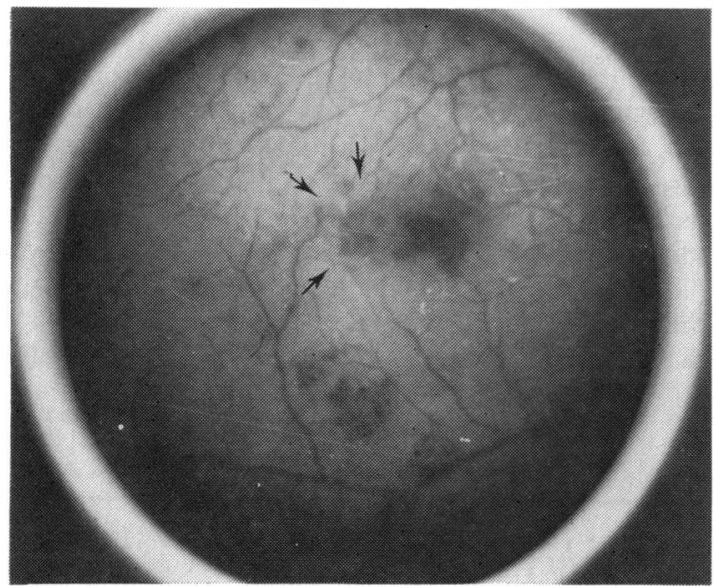

Fig. 2 Same patient as in Fig. 1, 17 months after operation. Although pigment deposits in the foveola and fovea persist, there is a relative diminution of their concentration and extent. It is also to be noted that certain patches on the macula have vanished (see arrows).

Visual acuity remains unchanged $(0 \cdot 4)$

intervention. In all instances of preoperative pigment migration the location of the pigment was epiretinal. All 3 cases which presented macular pigment migration after surgery for retinal detachment also showed postoperative uveitis.

With respect to location, epiretinal pigment deposits were encountered: $(a)$ in cases with preoperative pigment migration, and $(b)$ in retinal detachments without any elevation of the macula.

In the cases of subretinal location of the pigment deposits there invariably pre-existed a preoperative macular elevation, while the retinal detachment was pre-eminently superior or superor-temporal. Subretinal pigment deposits were observed during surgery or immediately afterwards.

\section{EVOLUTION OF THE PIGMENT DEPOSITS}

In the cases in which the pigment deposits were subretinal alterations of the pigment were observed, although they were smaller in extent and number than those in the group with epiretinal deposits (Figs. 1 and 2). The latter presented changes consisting in the displacement of the pigment from the foveola to the fovea or even farther away and in the diminution of the size of the pigment spots or patches. These were observed in 4 of the 10 cases with epiretinal pigment deposits (Figs. 3 and 4).

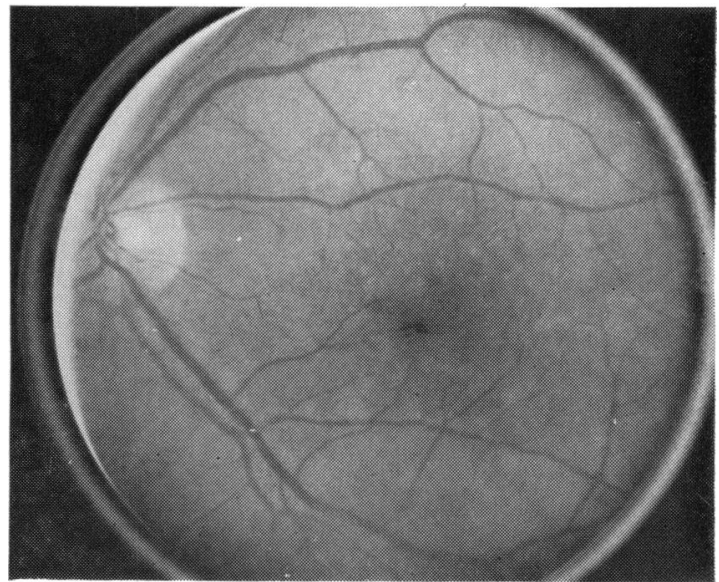

Fig. 3 Pigment accumulations of epiretinal type on the foveola and fovea 3 months after operation. Visual acuity 0.9

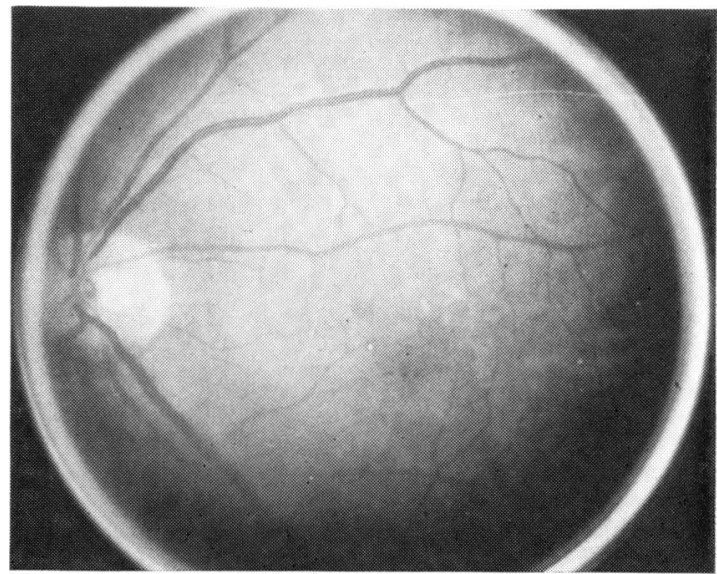

Fig. 4 The same case as Fig. 3, 27 months after operation. Note that the pigment deposits have almost dispersed 
The changes in the pigment migration were noted after the first 12 months following the operation.

Six out of the 20 cases with pigment deposits in the foveola or fovea developed postoperative puckering of the macula. In all these 6 eyes pigment deposits preceded the macular puckering, which occurred 4 months or more after the operation. The appearance of macular puckering in the group with pigment deposits is statistically significant, since it arose in 6 out of 20 cases, whereas in the comparison group none of the 20 cases was subject to it $(P<0.01)$. Macular puckering was more frequent (5 out of the 6 eyes) in cases of epiretinal deposits of the spotted type.

Details concerning the relation between macular puckering and the type and location of the pigment and the time of onset after the surgery for the detachment are set out in Table 2. It should also be noted that in the group with pigment migration there was 1 case with a partial macular hole and 1 with cystoid macular degeneration. The partial macular hole appeared after the fourth month and the cystoid degeneration 1 year after the operation (Fig. 5).

\section{EFFECTS ON FUNCTIONAL CONDITION OF THE MACULA}

In the 14 cases with macular pigment migration in which no puckering of the macula was observed the greatest improvement of visual acuity was achieved within the same time as in the group without

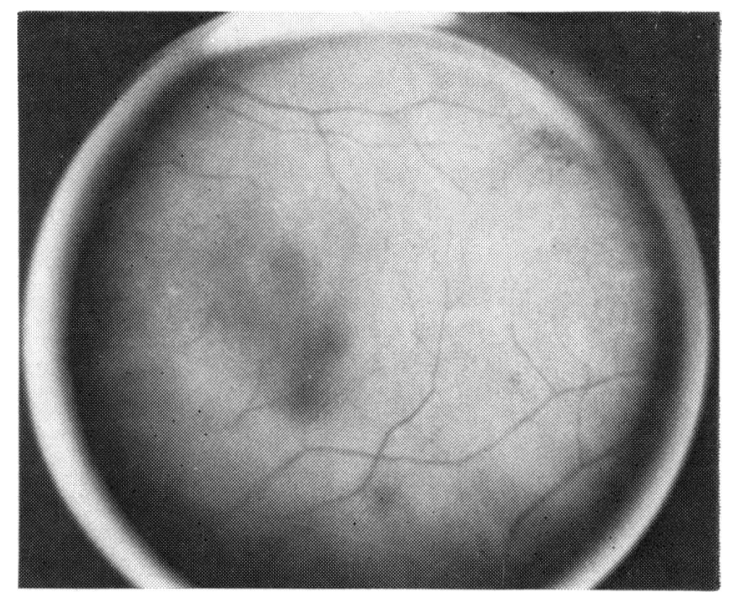

Fig. 5 Pseudohole of the macula which developed 4 months after operation in a 53-year-old patient. The pigment covers two-thirds of the macular periphery but is more evident in the inferior temporal area

pigment migration, mainly in the first 6 months after operation. Average visual acuity, however, was better in the group without pigment migration, given the fact that 12 out of the 14 eyes in this group had better visual acuity taken singly and all 14 in the aggregate at 3,6, and 24 months after operation (Tables 4 and 5, Fig. 6). It should be pointed out that to facilitate comparison the 6 cases with macular puckering of the group with macular

Table 4 Comparison between visual acuity of the 2 groups up to the 6th postoperative month*

\begin{tabular}{|c|c|c|c|c|c|c|}
\hline \multirow{3}{*}{$\begin{array}{l}\text { Case } \\
\text { no. }\end{array}$} & \multicolumn{6}{|l|}{ Visual acuity } \\
\hline & \multicolumn{3}{|c|}{ Group with macular pigment migration } & \multicolumn{3}{|c|}{ Group without pigment migration } \\
\hline & Preoperation & $\begin{array}{l}3 \text { months after } \\
\text { operation }\end{array}$ & $\begin{array}{l}6 \text { months after } \\
\text { operation }\end{array}$ & Preoperation & $\begin{array}{l}3 \text { months after } \\
\text { operation }\end{array}$ & $\begin{array}{l}6 \text { months after } \\
\text { operation }\end{array}$ \\
\hline 1 & 0.05 & $0 \cdot 3$ & $0 \cdot 3-0 \cdot 4$ & HM & 0.5 & 0.7 \\
\hline 2 & 0.05 & 0.4 & 0.5 & HM & 0.9 & 0.9 \\
\hline 3 & HM & 0.3 & 0.4 & HM & 0.4 & $0.6-0.7$ \\
\hline 4 & CF & $0 \cdot 3$ & $0 \cdot 3$ & $\mathbf{C F}$ & $0 \cdot 3$ & $0 \cdot 4$ \\
\hline 5 & $0 \cdot 2$ & $0 \cdot 1$ & $0 \cdot 1$ & $0 \cdot 2$ & $0 \cdot 6$ & $0.7-0.8$ \\
\hline 6 & $0 \cdot 3$ & $0.4-0.5$ & 0.5 & HM & $0 \cdot 3$ & $0 \cdot 6$ \\
\hline 7 & HM & $0 \cdot 2$ & $0 \cdot 2-0 \cdot 3$ & 0.05 & $0 \cdot 2-0 \cdot 3$ & $0 \cdot 3$ \\
\hline 8 & CF & $0 \cdot 2$ & $0 \cdot 3$ & CF & $0 \cdot 3$ & 0.6 \\
\hline 9 & $0.8-0.9$ & 0.9 & 0.9 & $0 \cdot 3$ & $0.6-0.7$ & $0 \cdot 8$ \\
\hline 10 & HM & $0 \cdot 7$ & $0.7-0.8$ & CF & 0.4 & $0.5-0.6$ \\
\hline 11 & $\mathbf{H M}$ & $0.2-0.3$ & 0.3 & HM & 0.6 & 0.7 \\
\hline 12 & $0 \cdot 3$ & 0.4 & 0.5 & $0 \cdot 3-0.4$ & 0.3 & 0.4 \\
\hline 13 & 0.9 & 0.8 & $0.8-0.9$ & 0.9 & 0.9 & 0.9 \\
\hline 14 & 0.9 & 0.9 & 0.9 & 0.9 & 0.9 & 0.9 \\
\hline
\end{tabular}

- Cases of macular puckering of group $A$ have been omitted, as well as the 6 corresponding cases without puckering from group $B$. HM = hand movements, $\mathrm{CF}=$ counting fingers 
Table 5 Statistical analysis of improvement of visual acuity in groups $\mathrm{A}$ and $\mathrm{B}$ in the 3rd, 6th, and 24th postoperative month

\begin{tabular}{llll}
\hline \multicolumn{4}{l}{ Group A. Initial visual acuity/3, 6, 24 postoperative month } \\
\hline $\begin{array}{l}\text { Months after } \\
\text { operation }\end{array}$ & $\mathrm{t}$ value & Probability & Significance \\
\hline 3 & 1.56 & $\mathrm{P}>0.1$ & No \\
6 & 2.00 & $\mathrm{P}<0.1$ & Yes \\
24 & 2.29 & $\mathrm{P}<0.05$ & Yes \\
\hline
\end{tabular}

Group B. Initial visual acuity/3, 6, 24 postoperative month

\begin{tabular}{llll}
\hline $\begin{array}{l}\text { Months after } \\
\text { operation }\end{array}$ & $\mathrm{t}$ value & Probability & Significance \\
\hline 3 & 3.03 & $\mathrm{P}<0.01$ & Yes \\
6 & 4.57 & $\mathrm{P}<0.001$ & Yes \\
24 & 5.27 & $\mathrm{P}<0.001$ & Yes \\
\hline
\end{tabular}

Progress of group A/progress of group B

\begin{tabular}{llll}
\hline $\begin{array}{l}\text { Months after } \\
\text { operation }\end{array}$ & $\mathrm{t}$ value & Probability & Significance \\
\hline 3 & $1.62<1.7$ & $\mathrm{P}>0.1$ & Not or hardly significant \\
6 & 2.34 & $\mathrm{P}<0.05$ & Yes \\
24 & 2.45 & $\mathrm{P}<0.05$ & Yes \\
\hline
\end{tabular}

pigment migration were excluded, as also were the 6 corresponding cases without macular puckering of the comparison group.

The 100 hue test did not reveal any differences between the 2 groups in respect of colour perception, nor were any differences observed in the ERG between the 2 groups. In contrast the group with pigment migration showed defects by static perimetry (Fig. 7).

For the latter examination eyes were selected from among both groups having a visual acuity of at least 0.7 and over and subjected to kinetic and static perimetry after the sixth postoperative month and later. During static perimetry it was observed that the pigment deposits, irrespective of type and form, gave rise to corresponding defects in the visual field, whereas the results of kinetic and static perimetry in group $B$ showed no such defects.

\section{Discussion}

It has been established that after a rhegmatogenous retinal detachment, and in particular after its surgical treatment, pigment migrates and is deposited anywhere in the fundus. The location of the pigment after the onset of the detachment and before the surgical operation has been clinically observed by Theodossiadis et al. (1975a, b) as well as experimentally established by Laqua and Machemer (1975). Preoperative pigment migration was more frequent in aphakic eyes which had recently undergone surgery for cataract.

Generally speaking, macular pigment migration was relatively more frequent in cases with upper temporal location of the tears $(P<0 \cdot 1)$, while generally with a superior location of the tears migration to the macular area was even more frequent and statistically significant $(P<0.025)$. In such cases and under the given conditions it would perhaps be advisable to position the patient's head with an upper nasal or temporal turn, depending on the location of the tears, during the first and perhaps second postoperative day.

The further evolution of the pigment depended on the type of the pigment deposit. Thus, in the epiretinal type 4 cases showed a marked diminution or displacement of the pigment away from the macula, occurring after the first 12 months after operation and resulting in 2 cases in an improvement of visual acuity.

So far there is no satisfactory explanation of the effects on the macula's functional condition of the
Fig. 6 Comparative study of visual acuity in groups $\mathrm{A}$ and $\mathrm{B}$ preoperatively and 2 years after operation

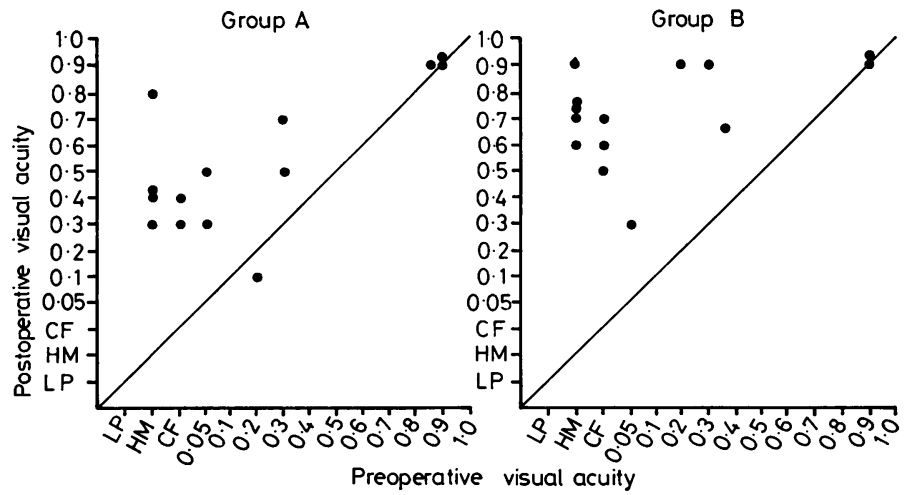



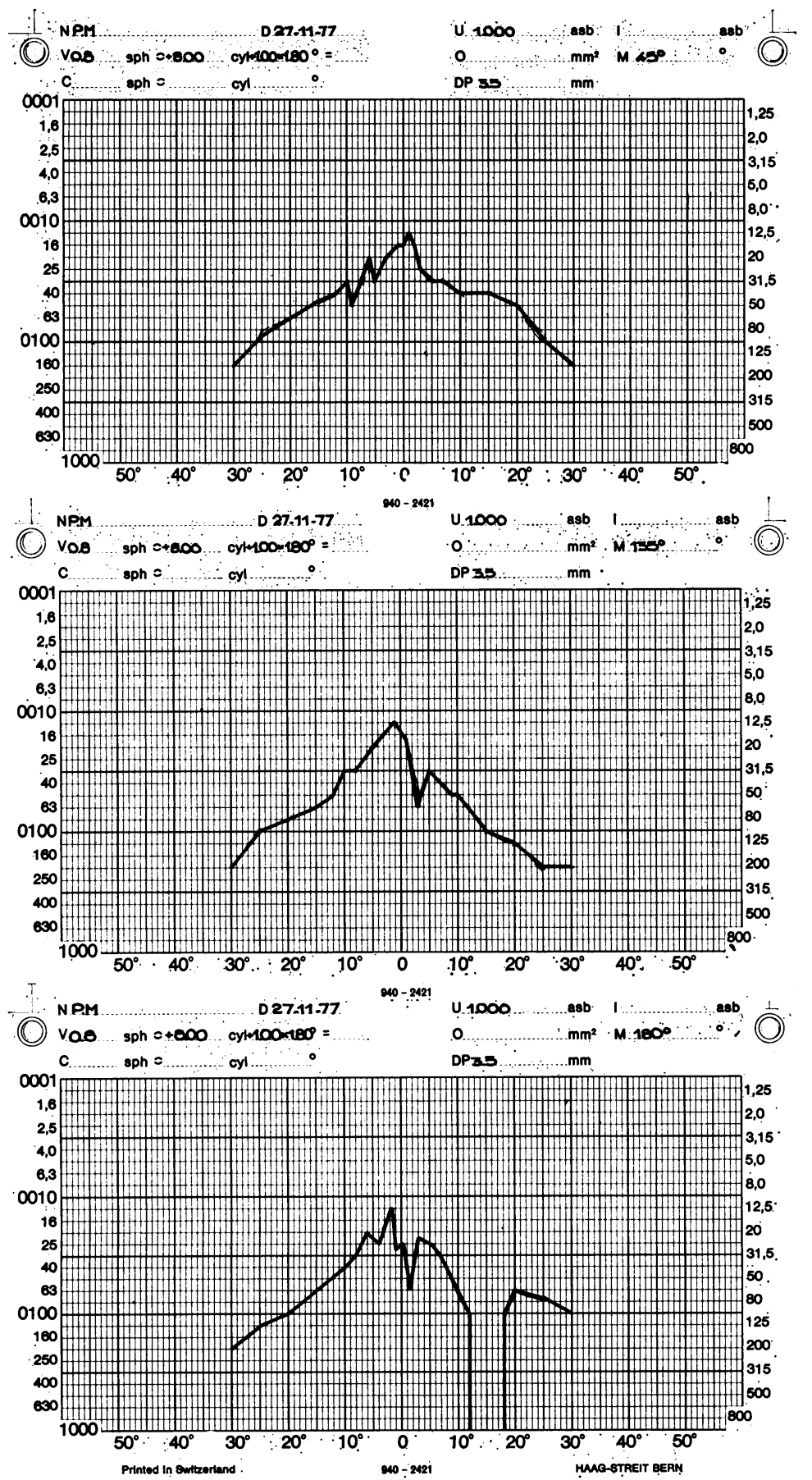

Fig. 7 Static perimetry in a 60-year-old patient with epiretinal pigment migration. Visual acuity $0 \cdot 8$. Note defects corresponding to the pigment deposits 


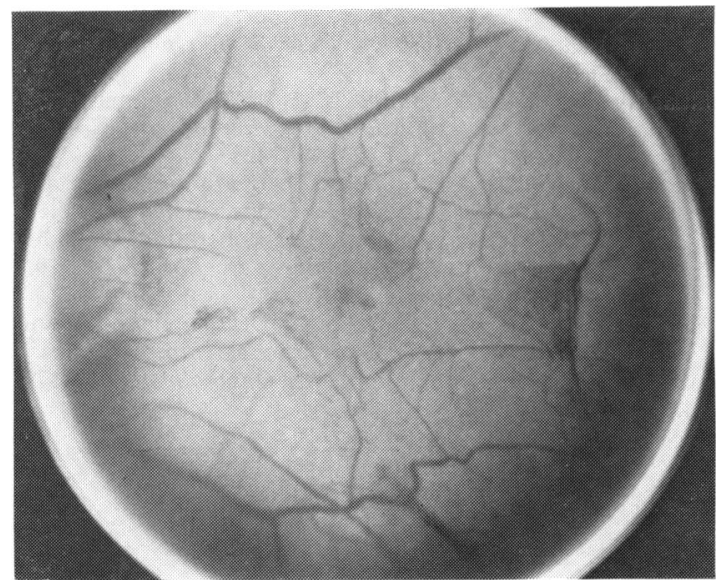

Fig. 8 Epiretinal pigment membrane at the posterior pole of the eyeball in a patient aged 70 . The membrane resulted in the formation of macular puckering. The pigment in this case was of the mixed type

migration and deposition of pigment in this area, and the views that have been put forward are in many respects controversial.

Thus, Sudarsky and Yannuzzi (1970) stated that pigment in the fovea is probably the most serious complication in cryosurgery, but that statistical evidence was still required to prove this. Norton (1969) likewise drew attention to the risks of excessive freezing and indicated the need for further investigation into the effect of pigment on the visual function. Abraham and Shea (1969) stressed that the effect of pigment accumulation on vision still awaits clarification and that pigment is likely to induce a relative scotoma corresponding to the site of its accumulation. Hilton (1974) claimed on the contrary that visual acuity and the function of the macula in general are not affected by macular pigment migration and deposits.

Our own results argue in favour of the view that the function of the macula is indeed impaired by the migration and deposition of pigment on it. This fact emerges from the comparison of the visual acuity of our 2 groups of patients with and without deposits of macular pigment. The comparison clearly shows that the cases of the group without pigment migration had better visual acuity 3, 6, and 24 months after operation (Tables 4 and 5, Fig. 6). The difference in visual acuity is statistically significant, especially after the first 6 months $(P<0 \cdot 05)$.

It should be noted that no difference was established in respect of visual acuity between the groups with epiretinal and with subretinal pigment migration.

Furthermore, static perimetry in the cases of the group with pigment deposits and visual acuity equal to or above 0.7 has shown that there is a relative defect corresponding to the pigment accumulation, whereas in the control group with the same visual acuity and without pigment deposits static perimetry showed no defect.

Pigment deposits in the macula, especially of the epiretinal type, seem to lead to macular puckering in a greater proportion of instances than when there are no pigment deposits (Fig. 8). This observation is statistically significant $(P<0.01)$, as appears from the analysis of our cases (Table 2). Puckering consequent upon pigment migration was also noted by Robertson and Buettner (1977) and by Clarkson et al. (1977). An explanation of this phenomenon has been attempted by Laqua and Machemer (1975), Machemer and Laqua (1975), and Johnson and Foulds (1977), who on the strength of their experimental investigations have postulated that migrating cells from the pigment epithelium may act as macrophages, and that these cells conjointly with glial cells are partly responsible for preretinal and retroretinal membrane formation. Such membrane formation, however, does not invariably ensue and cannot always be predetermined. It must be noted that in our cases the appearance of puckering consequent upon the deposition of pigment occurred relatively later, that is, 4 months and later after the operation, than the usual occurrence of puckering without the presence of pigment deposits.

\section{References}

Abraham, R. K., and Shea (1969). Significance of pigment dispersion following cryoretinopexy: scotomata and atrophy. Modern Problems of Ophthalmology, 8, 455-461.

Bietti, G. B. (1934a). Criocausticazioni episclerali como mezzo di terapia nel distacco retinico. Bollettino $d^{\prime}$ Oculistica, 13, 576-581.

Bietti, G. B. (1934b). Weitere Beiträge zur Kenntnis des retrolentikularen Pigmentringes und zu seiner Entstehungsweise. Klinische Monatsblätter für Augenheilkunde, 93, 54-60.

Brihaye, M., and Oosterhuis, J. A. (1972). Experimental cryoapplication with variations in the pressure exerted on the sclera. Ophthalmologic Research, 3, 129-144.

Chignell, A. H., Clemett, R. S., and Revie, I. H. (1973). Pigment fallout and uveitis after cryotherapy. British Journal of Ophthalmology, 57, 156-164.

Clarkson, J. G., Green, W. R., and Massof, D. (1977). Preretinal membrane. American Journal of Ophthalmology, 84, 1-17.

Johnson, N., and Foulds, W. (1977). Observations in the retinal pigment epithelium and retinal macrophages in experimental retinal detachment. British Journal of Ophthalmology, 61, 564-572.

Hamilton, A. M., and Taylor, W. (1972). Significance of pigment granules in the vitreous. British Journal of Ophthalmology, 56, 700-706.

Hilton, G. F. (1974). Subretinal pigment migration (effects of cryosurgical retinal reattachment). Archives of Ophthalmology, 91, 445-451. 
Laqua, H., and Machemer, R. (1975). Clinical-pathological correlation in massive periretinal proliferation. American Journal of Ophthalmology, 80, 913-929.

Lincoff, H. A. (1967). Complications of cryosurgery of the retina. Second Annual Cryosurgery Conference. Wills Eye Hospital.

Machemer, R., and Laqua, H. (1975). Pigment epithelium proliferation in retinal detachment. American Journal of Ophthalmology 80, 1-23.

Norton, E. W. D. (1969). Cryotherapy in retinal detachment surgery. Transactions of the New Orleans Academy of Ophthalmology, 3, 140-141.

Norton, E. W. D. (1969). Retinal detachment in aphakia. Transactions of the American Ophthalmological Society, 61, 770-789.
Robertson, D. M., and Buettner, H. (1977). Pigmented preretinal membranes. American Journal of Ophthalmology. 83, 824-829.

Sudarsky, R. D., and Yannuzzi, L. A. (1970). Cryomarcation line and pigment migration after retinal cryosurgery, Archives of Ophthalmology, 83, 395-401.

Theodossiadis, G. P., Chatzoulis, D., Karantinos, D., and Magouritsas, N. (1975a). Observations sur les complications intraoculaires survenant après l'opération CustodisLincoff. Archives d'Ophtalmologie et Revue Générale d'Ophtalmologie, 35, 627-638.

Theodossiadis, G. P., Chatzoulis, D., Patelis, J., and Velissaropoulous, P. (1975b). Extraocular observations in episcleral Silastic sponge implants. Ophthalmologica, 171, $439-450$. 